\title{
FUND ALLOCATION STRATEGIES AND PROJECT SUSTAINABILITY: A CASE OF VISION CITY PROJECT IN KIGALI CITY
}

\author{
Mr. Kagiraneza Sebijumba ${ }^{1 *}$, Dr. Claude Rusibana ${ }^{2}$ \\ *lEmail: sebkagiraneza@gmail.com,Email: crusibana@gmail
}

*Corresponding Author: -

Email: sebkagiraneza@gmail.com

\begin{abstract}
: -
The intention of this research is to examine the contribution of fund allocation strategies and sustainability of Vision City Project in Kigali. This research project is guided by three specific objectives such as to determine the impact of participatory planning on the sustainability of the Vision City Project in Kigali, to analyze the role of rate of return on the sustainability of the Vision City Project in Kigali, to establish the relationship between fund allocation strategies and sustainability of the Vision City Project in Kigali. This study is significant to policy makers in terms of formulating policies that favor sustainability of the project. The study is also significant to the future researchers in terms of using it as point of reference in regard to fund allocation strategies and project sustainability. The descriptive research design was applied in this study with a target population of 120 employees of the project, the same number were considered for sample size because it is reasonable and the sampling technique applied here is census sampling techniques, questionnaire and interview guides helped to gatherer the collected data which was coded, analyzed, interpreted in relation to the study objectives. The results have indicate a significant positive correlation between participatory planning and rate of returns ( $p=.646$ and sig=.003), between project ownership and stakeholder satisfaction ( $p=742$ and sig=.000), and rate of returns and stakeholder satisfaction $(p=.536$ and sig=.000). Hence, the results confirm a significant positive relationship between project sustainability of vision city in Rwanda. The results have also revealed that $R$ coefficient .815 shows fund allocation strategies has a positive relationship with project ownership. The coefficient of determination $.665 R$ square also shows that fund allocation strategies explains $66.5 \%$ of the variability in project ownership. Hence, this implies that the predictors such as constant, consultative project design, participatory planning and rate of returns affect the progress of project ownership by $66.5 \%$ in Vision City Project. In conclusion, since the results of the study have proved that there is a positive significant relationship between fund allocation strategies and project sustainability. Thus, the researcher also recommends to the government to continue encourage the private sector, investors and big business owners to allocate their fund in promoting project which can be sustainable and benefit the general public. The researcher cannot forget to recommend seminars, study tours and workshops to private sector federation to promote skills and knowledge on the allocation of funds to make sure sustainability of both private sector and government.
\end{abstract}

\section{(a) $(\$)$}




\subsection{BACKGROUND OF THE STUDY}

Today there is a growing understanding of the need to develop methods, tools, and techniques to combine sustainability standards in managing projects to ensure fund allocation strategies to maximize profits, as well as developing need of information and concepts of how to undertake sustainability in project management ( Ebbesen \& Hope; 2013; Silvius \& Schipper, 2014).

Sustainability is one of the most essential issues to consider in the decision-making process at different stages of project-oriented organization (Daneshpour, 2015). It has to be an integrated part of a project to obtain and gain the targets of agency (Hope \& Moehler, 2014; Tufinio et al., 2013). The Association for Project Management recommended that self - reliance of project management team should be at the center of resolve fund allocation issue in the project to ensure project sustainability. However, the contemporary needs for project management team have failed to address issues related to sustainability of the project conducted by government agencies. Thus, to enhance sustainability of the project there is a need to equip project managers with fund allocation strategies, project management and operations (Eid, 2011, Silvius \& Schipper, 2010; Ebbesen \& Hope, 2013).

The concepts of sustainable development to project life cycle management in the manufacturing industry. They described three objectives for sustainable development including social equity, participatory planning, and environmental performance in project management life cycle issues (Gad, 2020). Project management techniques and instruments were assembled into toolboxes and manage sustainability of projects. Project sustainability has been developed for specific kinds of projects such as facilities and infrastructure projects (American Council of Engineering Companies, 2009).

The studies conducted by Brook \& Pagnanelli, (2014) and Tufinio et al., (2013) have mentioned that sustainability in construction projects have revealed that sustainable development and project management has a significant contribution in construction projects. A maturity model for integrated project management is enhanced to ensure fund allocation strategies which in turn promote the sustainability of the projects (Silvius \& Schipper, 2010). The model assesses the occasional level of project management maturity, business model, and the product and services provided to enhance sustainability of the project. A sustainability checklist (as a tool was developed at the 2010 IMPA Expert Seminar on Survival and Sustainability as Project Challenges) was once one of the foundations for developing this model of maturity. Since sustainability is one of the most important issues in project management and fund allocation strategies, it is obvious that studying the impact of fund allocation strategies on project sustainability.

\subsection{Problem statement}

Globally, poor strategies for effective fund allocation have become a persistent problem to both projects conducted in developed countries and developing countries. Thus, the poor strategies have increase the rate of misallocation of public funds, misappropriation of public resources due to inefficient terms of public participation in planning and figuring out the rate of returns of the project which hinder the sustainability of the projects (Ababa, 2013). Government projects and non-government organizations face the same problems of unsupported withdraw of money, mismanagement and misallocation of funds which do not affect the project managers and financial controllers due to less level of participation of project stakeholders (Hope \& Moehler, 2014). Though, it well known that what makes a project to be sustainable is the level of inclusivity of its stakeholders. This is what differentiates project success, failure and sustainability.

Misallocation of funds are favored by poor strategies used in project design that leave a gap for fraudulent activities during project execution and this in turn hinders project sustainability. One of the key factors of effective fund allocation is the strategies applied by project stakeholders such as consultative project design, participatory planning and rate of return to enhance project sustainability (Peter et al., 2015). For the case of Rwanda, the office of auditor general has identified the issues of public fund misallocation and mismanagement in 2012 by the former EWASA (OAG, 2013). However, up to today the misallocated amount of money which goes around 1.1 million of US dollars $(648,958,517$ Rwandan Francs) are not refunded back.

The misallocation of $628,210,990$ Rwandan Francs along with 29 fraudulent cases excluding the case of misallocated materials of TIG and 960 iron sheets of 9 - YBE in 2011 report of OAG have not refunded due to poor strategies of fund allocation. Though, the Government has made efforts to reveal the fraudulent activities and mismanagement of $537,090,353$ Rwandan francs, the embezzled materials in 22 fraudulent cases, the unsupported withdrawals of 66,169,071 Rwandan francs in the Kigarama Sector in Kicukiro District, and the misallocation of 25,621,123 Rwandan francs in ONATRACOM have not been refunded back (Transparency International Rwanda, 2013). It is against this regards; the researcher wants to conduct a study on the impact of fund allocation strategies on the sustainability of the project.

\subsection{Objectives of the study}

\subsubsection{General objective}

The general objective is to assess the contribution of fund allocation strategies and project sustainability with specific consideration of Vision City Project in Kigali City - Rwanda as a case study.

\subsubsection{Specific Objectives}

(i) To examine the impact of participatory planning on sustainability of Vision City Project in Kigali City - Rwanda. 
(ii) To analyze contribution of rate of returns on sustainability of Vision City Project in Kigali City - Rwanda.

(iii) To establish relationship between fund allocation strategies and project sustainability of Vision City Project in Kigali City - Rwanda.

\subsection{Significance of the Study}

The results contributed of the existing body of knowledge and skills that will be used by other researchers, to do other studies in future. The study findings were useful source of information to the researchers, public and private institutions to ensure fund allocation strategies to enhance projects sustainability.

The study findings helped the community to know and find out the relationship between fund allocations strategies to enhance project sustainability.

The study contributed to the form of tools used by project management to build the capacity of their project through fund allocation to enhance growth and sustainability of the projects.

\subsection{Conceptual framework}

The conceptual work is a set of great idea and thoughts extracted from the relevant research and used to measure a subsequent presentation. The conceptual framework of Kombo and Tromp (2006) explains the relationship

between interconnected ideas and also explains the conceivable connection between variables. For instance relationship between fund allocation strategies as independent variable, project sustainability that is presented as dependent variable and intervening factors such as inflation, fiscal and taxation policies, and infrastructure development.

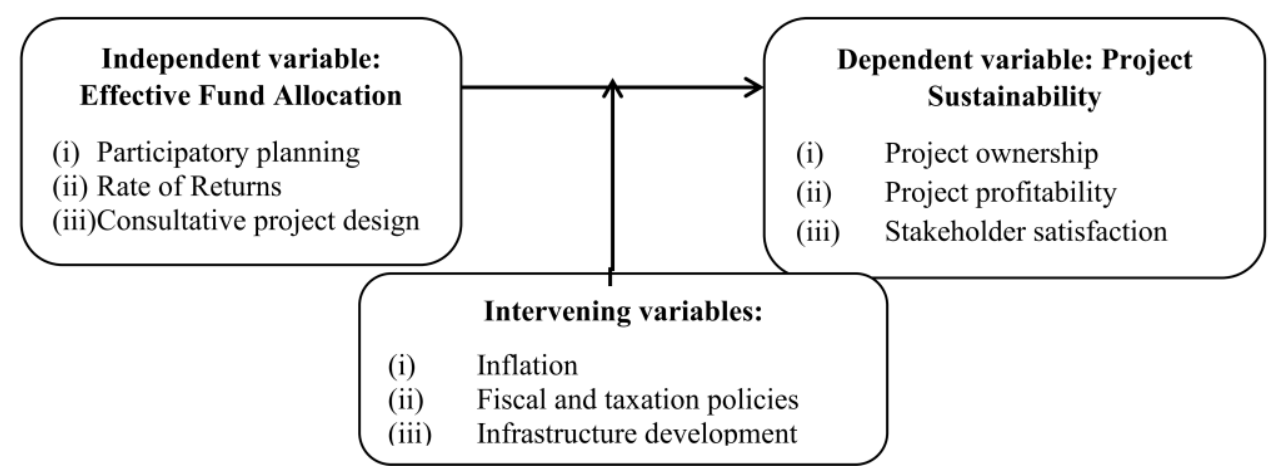

Source: Researcher, 2020

Figure 2. 1: Conceptual Framework

Conceptual framework represents the independent variable as fund allocation strategies and dependent variable as project sustainability. The fund allocation strategies have planning, rate of returns, consultative project design while project sustainability is measured in terms of project ownership, project profitability, and stakeholder satisfaction. It also reveals that apart from fund allocation strategies, other factors such as inflation, fiscal and taxation policies and infrastructure development may affect the results in sustainability of Vision city project.

Thus, show that there is a relationship between fund allocation strategies with its indicators which are participatory planning, rate of returns and consultative project design and project sustainability with its indicators which are project ownership, project profitability, and stakeholder satisfaction.

\subsection{Research Design}

The researcher has adopted descriptive research design to capture the detailed information in regard to fund allocation strategies and project sustainability. This descriptive research design was applied to help the researcher to collect both qualitative and quantitative information because they built a broader picture with the assist of including depth and views of numbers through together with talks and narratives, added accuracy to sentences with the aid of inclusive of numbers that will offer more than one view of seeing the results of the study.

Descriptive research design is used to analyze the situation, facilitated taking pictures of the situation on the field in a range of perspectives, and facilitated a deliberate minimal statistical analysis to enable quantitative accuracy of the findings. This research is about Vision City Project in of Kigali City, Rwanda, due to the fact it precisely shows the features of the fund allocation strategies and sustainability of the project, for this purpose used to decrease the bias of the guidelines and the reliability of the evidence gathered used maximized source of data as Amin (2005) supports the use of research design when collecting data.

\subsubsection{Sampling Size Determination}

The researcher used census sampling techniques to select the total number of respondents because the targeted population of this study is reasonable. Thus, implies that the whole target population of 120 respondents was involved in this study. 
Figure 3. 1: Sample Size Stratification

\begin{tabular}{lll}
\hline Respondents & Sample size & Sampling technique \\
\hline Project Staff & & Census \\
Monitors & 40 & Census \\
Beneficiaries & 10 & Census \\
Engineers & 60 & Census \\
Total & 10 & Census \\
\hline
\end{tabular}

Source: Vision City Project, 2020

\subsubsection{Instruments of Data Collection}

The researcher has used different tools to collect data from the field which were questionnaire as the tool used to collect data from the respondents. The researcher has used the questionnaire to collect the information from the respondents of the study. This tool helped the investigation to achieve the right of entry to the most important information of the study which is mostly quantitative data of the research project.

The method of unstructured observations was used in this study to allow the researcher to view beyond the situation on the field because this involves even structure features that could demonstrate the rate of sustainability of the project in relation the building of Vision City project and how this project is likely to be sustainable through its performance in changing the lives of the houseless in the city of Kigali. The collection of secondary data was also used as another method of data collection to ensure that all the relevant data are collected to enhance the analysis of the primary data of this study. The secondary data were accrued from documentaries, and annual reports.

\subsection{Data Analysis}

This part of the study involved organizing and inspecting the information that was gathered from the subject matter in order to come up with a very comprehensive report. The researcher made the necessary editing, tabulation and interpretation of data. The gathered data was coded, cleaned through vivid examinations, and analyzed through the use of SPSS version 21.0 to have descriptive statistics, and multiple linear regression correlation.

The correlation analysis, the Pearson correlation was applied in establishing the relationship between the independent and dependent variable. For linear regression analysis, a couple of regression model was applied with the aid of which $\mathrm{Y}$ $=\beta 0+\beta 1 \mathrm{X} 1+\beta 2 \mathrm{X} 2+\beta 3 \mathrm{X} 3$, with the aid of which $\mathrm{Y}$ is fund allocation strategies, $\beta$ o is constant, $\mathrm{X} 1$ is project ownership, X2 is project profitability, and X3 is stakeholder satisfaction and their inferential statistics are presented.

\subsection{Presentation of Findings}

This subsection represents the results in relation to objectives, to examine impact of Participatory planning to project sustainability with specific consideration of Vision City Project, to establish relationship between rate of returns and project sustainability of Vision City Project, to analyze the role of consultative project design on project sustainability of Vision City Project.

\subsubsection{The impact of Participatory planning on project sustainability}

This subsection, presents the views of the respondents in relation to the impact of Participatory planning and project sustainability

Table 4. 1: Descriptive statistics presenting statements regarding Participatory planning on project sustainability

\begin{tabular}{|c|c|c|c|c|c|c|c|}
\hline Statement & 5 & 4 & 3 & 2 & 1 & Mean & Std. D \\
\hline $\begin{array}{l}\text { Joint Actions affects sustainability } \\
\text { Vision City Project }\end{array}$ & $2(1.7 \%)$ & $1(0.8 \%)$ & $21(17.5 \%)$ & $47(39.2 \%)$ & $49(40.8 \%)$ & 2.6000 & .74923 \\
\hline $\begin{array}{l}\text { Decision effectiveness enhance } \\
\text { sustainability of vision city project }\end{array}$ & $1(0.8 \%)$ & $2(1.7 \%)$ & $79(65.8 \%)$ & $24(20.0 \%)$ & $14(11.7 \%)$ & 2.0833 & .95779 \\
\hline $\begin{array}{l}\text { Employee commitment promote } \\
\text { sustainability of vision city project }\end{array}$ & $3(2.5 \%)$ & $5(4.2 \%)$ & $27(22.5 \%)$ & $49(40.8 \%)$ & $36(30.0 \%)$ & 2.0917 & .99575 \\
\hline $\begin{array}{l}\text { Engaging employees in participatory } \\
\text { planning affects sustainability of vision } \\
\text { city project }\end{array}$ & $3(2.5 \%)$ & $7(5.8 \%)$ & $26(21.7 \%)$ & $46(38.3 \%)$ & $38(31.7 \%)$ & 2.1750 & .69406 \\
\hline $\begin{array}{l}\text { Participative support in project design } \\
\text { affects Sustainability of Vision City } \\
\text { Project }\end{array}$ & $3(2.5 \%)$ & $2(1.7 \%)$ & $17(14.2 \%)$ & $89(74.2 \%)$ & $9(7.5 \%)$ & 1.8750 & .86542 \\
\hline $\begin{array}{l}\text { Working capital influences } \\
\text { sustainability of vision city project }\end{array}$ & $1(0.8 \%)$ & $1(0.8 \%)$ & $19(15.8 \%)$ & $58(48.3 \%)$ & $41(34.2 \%)$ & 1.9167 & .97518 \\
\hline $\begin{array}{l}\text { Enhancing employee morale enhances } \\
\text { Sustainability of Vision City Project }\end{array}$ & $3(2.5 \%)$ & $1(0.8 \%)$ & $31(25.8 \%)$ & $33(27.5 \%)$ & $52(43.3 \%)$ & 2.6667 & .81306 \\
\hline $\begin{array}{l}\text { Accessibility to credit affect } \\
\text { Sustainability of Vision City Project }\end{array}$ & $3(2.5 \%)$ & $3(2.5 \%)$ & $79(65.8 \%)$ & $21(17.5 \%)$ & $14(11.7 \%)$ & 2.0583 & .91022 \\
\hline $\begin{array}{l}\text { Participation of Tenants in maintenance } \\
\text { of houses Sustainability of Vision City } \\
\text { Project }\end{array}$ & $3(2.5 \%)$ & $7(5.8 \%)$ & $26(21.7 \%)$ & $46(38.3 \%)$ & $38(31.7 \%)$ & 2.1750 & .69206 \\
\hline Total Mean & & & & & & 2.1500 & \\
\hline
\end{tabular}

Source: Primary Data, 2020 
The Table 4.1 extracted from the Likert Scale data of 5 point ( where 5 is not, 4 to no extent, 3 to less extent, 2 to great extent, 1 to a very great) the [mean=1.8750, $\mathrm{SD}=.86542$ ] with $89(74.2 \%)$ of respondents asserted that participative support in project design affects Sustainability of Vision City Project to a moderate extent. The [mean=2.0833, $\mathrm{SD}=.95779$ ] with $79(65.8 \%)$ of respondents asserted that decision effectiveness influence sustainability of vision city project to a small extent, the [mean=2.0583, $\mathrm{SD}=.91022]$ with $79(65.8 \%)$ of respondents asserted that accessibility to credit affects sustainability of vision city project to a small extent, the [mean=2.0917, SD=.99575] with 49 (40.8\%) of respondents asserted that Employee commitment promote sustainability of vision city project to a moderate extent, the [mean=1.8750, SD=.86542] with $49(40.8 \%)$ of respondents asserted that commercialization of the profit affects sustainability of vision city project to a moderate extent, and the [mean=1.8750, SD=.86542] with 46 (38.3\%) of respondents asserted that quality of tenants affect sustainability of vision city project to a moderate extent. The overall perception is 2.1500 which stand for a great extent of participatory planning on sustainability of Vision City project in Kigali City, Rwanda.

Table 4. 2: Model Summary of participatory planning and sustainability of vision city project in Kigali City

\begin{tabular}{lllll}
\hline Model & R & R Square & Adjusted R Square & Std. Error of the Estimate \\
\hline $.815^{\text {a }}$ & .665 & .653 & .34288 \\
\hline
\end{tabular}

a. Predictors: (Constant), Participatory planning, consultative project design, Rate of returns

Source: Primary Data 2020

The Table 4.2 revealed R coeffient. 815 shows participatory planning has a significant relationship to sustainability of the project. Coefficient of determination .665 R square also shows that participatory planning explains $66.5 \%$ of the variability in project sustainability. Hence, this implies that the predictors such as constant, participatory planning affect the progress of project sustainability by $66.5 \%$ in Vision City Project.

Table 4. 3: Coefficients of participatory planning and sustainability of vision city project in Kigali City

\begin{tabular}{llllll}
\hline Model & \multicolumn{2}{l}{ Unstandardized Coefficients } & $\begin{array}{l}\text { Standardized } \\
\text { Coefficients } \\
\text { Beta }\end{array}$ & T & Sig. \\
& $\mathrm{B}$ & Std. Error & .162 & & \\
\hline (Constant) & .641 & .059 & .790 & 12.135 & .000 \\
Participatory planning & .720 & .350 & .199 & .420 & .005 \\
Rate of returns & .147 & .346 & .130 & .277 & .002 \\
Consultative project design & .096 & &
\end{tabular}

a. Dependent Variable: project sustainability

Source: Primary Data, 2020

The table 4.4 demonstrates that participatory planning has a positive coefficient that enhances the positive effect on the project sustainability of vision city. The regression analysis indicates a significant relationship between participatory planning and project sustainability because all the calculated p-value is less that significance level of 0.05 . Thus, there is significant relationship between project sustainability and participatory planning. Based on coefficients and regression model: $Y=\beta 0+\beta 1 \times 1+\beta 2 \times 2+\beta 3 \times 3$, therefore it becomes $Y=.641+.720 \times 1+.147 \times 2+.096 \times 3$, this shows clearly a significant relationship between participatory planning and sustainability of vision city project. There is a positive and significant relationship between Participatory planning and project sustainability has a positive and significant relationship because the calculated p-value is less than

0.05 level of significance $(b=.720$ and sig=.000) because the calculated p-value is less than 0.05 level of significance. This means that participatory planning has a positive significant impact on sustainability of vision city project implying that the null hypothesis will be rejected.

Table 4. 4: Statements regarding the effect of participatory planning on project sustainability

\begin{tabular}{|c|c|c|c|c|c|c|c|}
\hline Statement & 5 & 4 & 3 & 2 & 1 & Mean & Std. D \\
\hline $\begin{array}{l}\text { Project ownership promotes project } \\
\text { sustainability }\end{array}$ & $0(0.0 \%)$ & $0(0.0 \%)$ & $28(23.3)$ & $30(25.0 \%)$ & $62(51.7 \%)$ & 2.0667 & .95911 \\
\hline $\begin{array}{l}\text { Project profitability of beneficiaries } \\
\text { promote project sustainability }\end{array}$ & $0(0.0 \%)$ & $1(0.8 \%)$ & $12(10.0 \%)$ & $21(17.5 \%)$ & $86(71.7 \%)$ & 2.1500 & .70592 \\
\hline $\begin{array}{l}\text { stakeholder satisfaction promotes } \\
\text { project sustainability }\end{array}$ & $0(0.0 \%)$ & $0(0.0 \%)$ & $8(6.7 \%)$ & $28(23.3 \%)$ & $84(70.0 \%)$ & 1.8750 & .89407 \\
\hline $\begin{array}{l}\text { Participatory planning affects } \\
\text { project sustainability }\end{array}$ & $1(0.8 \%)$ & $0(0.0 \%)$ & $24(20.0 \%)$ & $24(20.0 \%)$ & $71(59.2 \%)$ & 1.8667 & .78786 \\
\hline $\begin{array}{l}\text { Consultation during project design } \\
\text { affects project sustainability }\end{array}$ & $1(0.8 \%)$ & $3(2.5 \%)$ & $23(19.2 \%)$ & $46(38.3 \%)$ & $71(59.2 \%)$ & 1.8917 & .95086 \\
\hline $\begin{array}{l}\text { Capacity build of staffs affect project } \\
\text { vision city project sustainability }\end{array}$ & $1(0.8 \%)$ & $1(0.8 \%)$ & $19(15.8 \%)$ & $58(48.3 \%)$ & $41(34.2 \%)$ & 2.6250 & .79982 \\
\hline $\begin{array}{l}\text { Tenants satisfaction promote } \\
\text { sustainability of vision city project }\end{array}$ & $3(2.5 \%)$ & $1(0.8 \%)$ & $31(25.8 \%)$ & $33(27.5 \%)$ & $52(43.3 \%)$ & 2.0083 & .855511 \\
\hline Total Mean & & & & & & $\begin{array}{l}2.0690 \\
5\end{array}$ & \\
\hline
\end{tabular}


The findings in Table 4.5 extracted from the Likert Scale data of 5 point (1- Strongly agree, 2- Agree, 3- Don't know, 4 Disagree, 5-Strongly Agree), the overall perception is 2.06905 confirming the effect of participatory planning on project sustainability. The [mean=2.066, SD=.95911] with $62(51.7 \%)$ of respondents strongly agreed that Project ownership promotes project sustainability. The [mean=2.6250, $\mathrm{SD}=.79982]$ with $58(48.3 \%)$ of respondents strongly agreed that capacity building of staffs and the [mean=2.0083, $\mathrm{SD}=.8511$ ] with 52 (43.3\%) of respondents strongly agreed that tenants satisfaction promote sustainability of vision city project. The overall perception is 2.06905 implying that the null hypothesis will be rejected and accepts the alternative stating that participatory planning has an effect on project sustainability in Vision City project in Kigali, Rwanda.

\subsubsection{The contribution of rate of returns on project sustainability}

In this subsection, the researcher presents the views of respondents in relation to the contribution of rate of returns and project sustainability.

Table 4. 5: Descriptive Statistics presenting statements of rate of return enhancing project sustainability

\begin{tabular}{|c|c|c|c|c|c|c|c|}
\hline Statement & 5 & 4 & 3 & 2 & 1 & Mean & SD \\
\hline Skills of Workers affect project sustainability & $3(2.5 \%)$ & $4(3.3 \%)$ & $10(8.3 \%)$ & $94(78.30 \%)$ & $9(7.5 \%)$ & 2.058 & .989 \\
\hline Equipment Used affect project sustainability & $2(1.7 \%)$ & $3(2.5 \%)$ & $20(16.7 \%)$ & $48(40.0 \%)$ & $47(39.2 \%)$ & 2.100 & .599 \\
\hline stakeholder satisfaction to project sustainability & $0(0.0 \%)$ & $0(0.0 \%)$ & $8(6.7 \%)$ & $28(23.3 \%)$ & $84(70.0 \%)$ & 1.850 & .856 \\
\hline $\begin{array}{l}\text { Machinery Used affect sustainability Vision City } \\
\text { Project }\end{array}$ & $1(0.8 \%)$ & $2(1.7 \%)$ & $18(15.0 \%)$ & $58(43.3 \%)$ & $41(34.2 \%)$ & 1.925 & .821 \\
\hline $\begin{array}{l}\text { Work Experience affects sustainability Vision } \\
\text { City Project }\end{array}$ & $2(1.7 \%)$ & $2(1.7 \%)$ & $30(25.0 \%)$ & $33(27.5 \%)$ & $53(44.2 \%)$ & 1.833 & .891 \\
\hline $\begin{array}{l}\text { Capital per worker affects sustainability Vision } \\
\text { City Project }\end{array}$ & $3(2.5 \%)$ & $1(0.8 \%)$ & $78(65.0 \%)$ & $24(20.0 \%)$ & $14(11.7 \%)$ & 2.591 & .739 \\
\hline $\begin{array}{l}\text { Professional and Scientific Used Equipment } \\
\text { affect sustainability Vision City Project }\end{array}$ & $1(0.8 \%)$ & $2(1.7 \%)$ & $30(25.0 \%)$ & $51(42.5 \%)$ & $36(30.0 \%)$ & 2.075 & .971 \\
\hline $\begin{array}{l}\text { Transportation Equipment affects sustainability } \\
\text { Vision City Project }\end{array}$ & $5(4.2 \%)$ & $2(1.7 \%)$ & $26(21.7 \%)$ & $49(40.8 \%)$ & $38(31.7 \%)$ & 2.041 & .947 \\
\hline $\begin{array}{l}\text { Business Openness affects sustainability Vision } \\
\text { City Project }\end{array}$ & $2(1.7 \%)$ & $1(0.8 \%)$ & $13(10.8 \%)$ & $95(79.2 \%)$ & $9(7.5 \%)$ & 2.691 & .848 \\
\hline $\begin{array}{l}\text { Technical Innovation affects sustainability Vision } \\
\text { City Project }\end{array}$ & $2(1.7 \%)$ & $1(0.8 \%)$ & $21(17.5 \%)$ & $58(48.3 \%)$ & $38(31.7 \%)$ & 2.058 & .946 \\
\hline $\begin{array}{l}\text { Skills of Partners affects sustainability Vision } \\
\text { City Project }\end{array}$ & $1(0.8 \%)$ & $1(0.8 \%)$ & $30(25.0 \%)$ & $33(27.5 \%)$ & $55(45.8 \%)$ & 1.991 & .845 \\
\hline Rate of returns affect project sustainability & $0(0.0 \%)$ & $0(0.0 \%)$ & $8(6.7 \%)$ & $28(23.3 \%)$ & $84(70.0 \%)$ & 2.191 & .736 \\
\hline Total Mean & & & & & & 2.117 & \\
\hline
\end{tabular}

Source: Primary Data, 2020

The findings in Table 4.6 extracted from the Likert Scale data of 5 point, the overall perception is 2.117 confirming the effect of participatory planning on project sustainability. The [mean=2.058, SD=.989] with $94(78.3 \%)$ of respondents asserted that skills of workers affect sustainability of vision city project to a moderate extent. The [mean $=1.850$, $\mathrm{SD}=.856]$ with $48(40.0 \%)$ of respondents asserted that equipment used affects sustainability of vision city project to a moderate extent. The [mean=1.925, $\mathrm{SD}=.821]$ with $58(48.3 \%)$ of respondents asserted that machinery used influences sustainability of vision city project to a moderate extent.. The [mean=1.991, SD=.845] with $55(45.8 \%)$ of respondents asserted that skills of partners affects sustainability of vision city project to a very great extent, and the [mean=2.191, $\mathrm{SD}=.736$ ] with $84(70.0 \%)$ respondents agreed that rate of returns affect the project sustainability. The overall perception is 2.117 meaning that the null hypothesis will be rejected and accepts the alternative stating that rate of returns has a positive significant effect on sustainability of vision city project in Kigali, Rwanda.

Table 4.6: Model summary of rate of returns and project sustainability of vision city in Kigali, Rwanda

\begin{tabular}{lllll}
\hline Model & R & R Square & Adjusted R Square & Std. Error of the Estimate \\
\hline $.662^{\mathrm{a}}$ & .439 & .420 & .47884 \\
\hline
\end{tabular}

a. Predictors: (Constant), rate of returns, Consultive project design, Participatory planning

Source: Primary Data, 2020

The results in table 4.7 revealed that $\mathrm{R}$ coeffient.662 shows rate of returns has a positive relationship with project sustainability of vision city project. The coefficient of determination $.439 \mathrm{R}$ square also shows that rate of returns explains $43.9 \%$ of the variability in project sustainability. Hence, this implies that the predictors such as constant, rate of returns affect the progress of sustainability by $43.9 \%$ in Vision City Project.

Table 4. 7: Coefficients of rate of returns and sustainability of vision city project in Kigali, Rwanda

\begin{tabular}{|c|c|c|c|c|c|}
\hline \multirow[t]{2}{*}{ Model } & \multicolumn{2}{|c|}{ Unstandardized Coefficients } & Standardized & $\mathrm{T}$ & Sig. \\
\hline & B & Std. Error & Beta & & \\
\hline (Constant) & .205 & .226 & & .908 & .366 \\
\hline Rate of returns & .200 & .489 & .250 & .409 & .004 \\
\hline Participatory planning & .430 & .083 & .438 & 5.195 & .000 \\
\hline Consultative project design & .104 & .483 & .131 & .216 & .030 \\
\hline
\end{tabular}

a. Dependent Variable: Project profitability

Source: Primary Data, 2020 
The findings in the table 4.9 revealed that the rate of returns has positive coefficients that enhance the positive effect on the project sustainability. The regression analysis indicates a significant relationship between rate of returns and project sustainability because all the calculated p-values are less that significance level of 0.05 . Thus, there is significant relationship between rate of returns and project sustainability. Based on coefficients and regression model: $\mathrm{Y}=\beta 0+\beta 1 \times 1+\beta 2 \times 2+\beta 3 \times 3$, therefore it becomes $\mathrm{Y}=.205+.430 \times 1+.200 \times 2+.104 \times 3$, this shows clearly a significant relationship between project sustainability and rate of returns in vision city project. The second objective of establishing the relationship between rate of returns and project sustainability because the calculated p-value is less than 0.05 level of significance $(b=.200$ and sig=.004) because the calculated $p$-value is less than 0.05 level of significance. Hence, this implies that the null hypothesis will be rejected and accept the alternative stating that rate of returns contribute to sustainability of vision city project in Kigali, Rwanda.

\subsubsection{The relationship between fund allocation strategies and project sustainability}

In this subsection, the researcher represents the research findings in relation to the fund allocation strategies and project sustainability.

Table 4.8: Descriptive Statistics presenting statements regarding find allocation strategies and project sustainability

\begin{tabular}{llllllll}
\hline Statement & 5 & 4 & 3 & 2 & 1 & Mean & Std. \\
\hline $\begin{array}{l}\text { Overhead and profit margin plays a big } \\
\text { role on sustainability Vision City project }\end{array}$ & $5(4.2 \%)$ & $1(0.8 \%)$ & $28(23.3 \%)$ & $50(41.7 \%)$ & $36(30.0 \%)$ & 1.8833 & .90918 \\
$\begin{array}{l}\text { Access to off-farm income plays a big } \\
\text { role on sustainability of vision city project }\end{array}$ & $1(0.8 \%)$ & $1(0.8 \%)$ & $80(66.7 \%)$ & $24(20.0 \%)$ & $14(11.7 \%)$ & 1.9500 & .83867 \\
$\begin{array}{l}\text { Cost of quality plays a big role on } \\
\text { sustainability Vision City Project }\end{array}$ & $4(3.3 \%)$ & $1(0.8 \%)$ & $29(24.2 \%)$ & $48(40 \%)$ & $38(31.7 \%)$ & 1.8500 & .94957 \\
$\begin{array}{l}\text { Volume Discounts plays a big role on } \\
\text { sustainability Vision City Project }\end{array}$ & $5(4.2 \%)$ & $1(0.8 \%)$ & $80(66.7 \%)$ & $20(16.7 \%)$ & $14(11.7 \%)$ & 1.8500 & .84809 \\
$\begin{array}{l}\text { Raw material plays a big role on } \\
\text { sustainability Vision City Project }\end{array}$ & $4(3.3 \%)$ & $2(1.7 \%)$ & $27(22.5 \%)$ & $51(42.5 \%)$ & $36(30.0 \%)$ & 1.9500 & .94643 \\
$\begin{array}{l}\text { Construction Time plays a big role on } \\
\text { sustainability Vision City Project }\end{array}$ & $1(0.8 \%)$ & $2(1.7 \%)$ & $30(25.0 \%)$ & $49(40.8 \%)$ & $38(31.7 \%)$ & 1.8833 & .84511 \\
$\begin{array}{l}\text { Certification and audits plays a big role } \\
\text { on sustainability Vision City Project }\end{array}$ & $2(1.7 \%)$ & $4(3.3 \%)$ & $19(15.8 \%)$ & $48(40.0 \%)$ & $47(39.2 \%)$ & 2.1917 & .73674 \\
$\begin{array}{l}\text { Control against Risk factor plays a big } \\
\text { role on sustainability Vision City Project }\end{array}$ & $2(1.7 \%)$ & $2(1.7 \%)$ & $21(17.5 \%)$ & $58(48.3 \%)$ & $37(30.8 \%)$ & 1.9917 & .90918 \\
$\begin{array}{l}\text { Location of the project plays a big role on } \\
\text { sustainability Vision City Project }\end{array}$ & $2(1.7 \%)$ & $1(0.8 \%)$ & $31(25.8 \%)$ & $29(24.8 \%)$ & $57(47.5 \%)$ & 2.0583 & .83867 \\
$\begin{array}{l}\text { consultative project design on project } \\
\text { sustainability }\end{array}$ & $10(8.5 \%)$ & $27(22.5 \%)$ & $83(69.2 \%)$ & $0(0.0 \%)$ & $0(0.0 \%)$ & 2.6917 & .94957 \\
\begin{tabular}{l} 
Total Mean \\
\hline
\end{tabular} & & & & & 2.0300 & \\
\hline
\end{tabular}

Source: Primary Data, 2020

The findings in Table 4.10 extracted from the Likert Scale data of 5 point (1- To a very great extent, 2- To a great extent, 3- To a small extent, 4- To no extent and 5 - not sure, the overall perception is 2.117 confirming the effect of participatory planning on project sustainability. The [mean=1.8833, SD=.90918] with $80(66.7 \%)$ of respondents asserted that access to off-farm income plays a big role on sustainability of vision city project to a small extent. The [mean $=1.9500, \mathrm{SD}=.83867$ ] with $50(41.7 \%)$ of respondents asserted that overhead and profit margin plays a big role on sustainability of vision city project to a moderate extent, [mean=1.8500, SD=.84809] with $80(66.7 \%)$ of respondents asserted that volume discounts plays a big role on sustainability of vision city project to a small extent. The [mean=1.9917, $\mathrm{SD}=.90918]$ with $83(69.2 \%)$ of respondents asserted that consultative project design on project sustainability, and the [mean=2.0583, $\mathrm{SD}=.83867$ ] with $57(47.5 \%)$ of respondents asserted that location of the project plays a big role on sustainability of vision city project to a very great extent. The overall perception is 2.0300 indicating that the null hypothesis will be rejected and accept the alternative stating that fund allocation strategies has an effect on project sustainability in Vision City project.

Table 4.9: Correlation Analysis between fund allocation strategies and Vision City Project Sustainability

\begin{tabular}{|c|c|c|c|c|}
\hline & & project ownership & Project profitability & $\begin{array}{l}\text { Stakeholder } \\
\text { Satisfaction }\end{array}$ \\
\hline \multirow{3}{*}{ Participatory planning } & P Correlation & $.603^{* *}$ & $.459^{* *}$ & $.578^{* *}$ \\
\hline & Sig. (2-tailed) & .000 & .000 & .000 \\
\hline & $\mathrm{N}$ & 120 & 120 & 120 \\
\hline \multirow{3}{*}{ Rate of returns } & P Correlation & $.508^{* *}$ & $.363^{* *}$ & $.536^{* *}$ \\
\hline & Sig. (2-tailed) & .000 & .000 & .000 \\
\hline & $\mathrm{N}$ & 120 & 120 & 120 \\
\hline \multirow{2}{*}{$\begin{array}{l}\text { Consultative } \\
\text { design }\end{array}$} & P Correlation & $.495^{* *}$ & $.439^{* *}$ & $.478^{* *}$ \\
\hline & $\begin{array}{l}\text { Sig. (2-tailed) } \\
\mathrm{N}\end{array}$ & .000 & .000 & .000 \\
\hline
\end{tabular}

**. Correlation is significant at the 0.01 level (2-tailed).

Source: Primary Data, 2020 
The findings in table 4.11 indicate that there is a positive correlation between fund allocation strategies and sustainability of vision city project because all the calculated $\mathrm{P}$-value is less than 0.01 level of significance; for instance, correlation analysis between participatory planning and project profitability $(\mathrm{p}=.450$ and sig=.000), participatory planning and stakeholder satisfaction $(\mathrm{p}=.578$ and $\mathrm{sig}=.000)$, rate of returns and project ownership ( $\mathrm{p}=.508$ and $\mathrm{sig}=.000)$, rate of returns and project profitability $(\mathrm{p}=.363$ and $\mathrm{sig}=.000)$, and rate of returns and stakeholder satisfaction $(\mathrm{p}=.536$ and sig=.000). This implies that the null hypothesis will be rejected and accept the alternative stating there is a positive and significant relationship between fund allocation strategies and vision city project sustainability in Kigali City, Rwanda.

Table 4. 10: Model Summary of fund allocation strategies and stakeholder satisfaction

\begin{tabular}{lllll}
\hline Model & $\mathrm{R}$ & $\mathrm{R}$ Square & Adjusted R Square & Std. Error of the Estimate \\
\hline & $335^{\mathrm{a}}$ & .112 & .082 & .86830 \\
\hline
\end{tabular}

a. Predictors: (Constant), Consultative project design, Participatory planning, Rate of returns

Source: Primary Data, 2020

The results in table 4.12 revealed that $\mathrm{R}$ coeffient.335 shows fund allocation strategies have a positive relationship with project profitability. The coefficient of determination .112 R square also shows that fund allocation strategies explains $11.2 \%$ of the variability in improved standards.

Hence, this implies that the predictors such as constant, consultative project design, participatory planning and rate of returns affect the progress of improved standards by $11.2 \%$ in Vision City Project.

Table 4. 11: Coefficients of fund allocation strategies and stakeholder satisfaction

\begin{tabular}{llllll}
\hline Model & \multicolumn{2}{l}{ Unstandardized Coefficients } & Standardized Coefficients t & Sig. \\
\hline & $\mathrm{B}$ & Std. Error & Beta & & \\
(Constant) & .980 & .409 & & 1.396 & .019 \\
Participatory planning & .283 & .150 & .199 & .003 \\
Rate of returns & .074 & .888 & -.064 & -.084 & .034 \\
Consultative project design & .320 & .875 & .280 & .366 & .015 \\
\hline
\end{tabular}

a. Dependent Variable: Stakeholder Satisfaction

Source: Primary Data, 2020

The findings in the Table 4.14 revealed that the predictors of fund allocation strategies have positive coefficients that enhance the positive effect on the stakeholder satisfaction. The regression analysis indicates a significant relationship between fund allocation strategies and stakeholder satisfaction because all the calculated p-values are less that significance level of 0.05 . Thus, there is significant relationship between stakeholder satisfaction and fund allocation strategies. Based on coefficients and regression model $\mathrm{Y}=.980+.283 \times 1+.074 \times 2+.320 \times 3$, this shows clearly a significant relationship between stakeholder satisfaction and fund allocation strategies of vision city project.

The first objective of establishing the relationship between stakeholder satisfaction and participatory planning has a positive and significant relationship because the calculated p-value is less than 0.05 level of significance $(b=.283$ and $\mathrm{sig}=.003$ ). The second shows relationship between rate of returns and stakeholder satisfaction because the calculated $\mathrm{p}$ value is less than 0.05 level of $\operatorname{sig}(b=.074$ and $\operatorname{sig}=.034)$. Whereas, the third shows relationship between consultative project design and stakeholder satisfaction $(b=.320$ and sig=.015) because the calculated $p$ - value is less than 0.05 level of significance. Thus, it implies that the null hypothesis will be rejected and accept the alternative stating that there is a relationship between fund allocation strategies and project sustainability.

\subsection{Conclusion}

The findings on the fund allocation strategies and project sustainability revealed that there is a considerable influence of fund allocation strategies to project sustainability through encouraging project ownership, improving standards of the living of the stakeholders, and encouraging their satisfaction as well as ensuring Participatory planning and rate of returns of the vision city project. The results revealed that $\mathrm{R}$ coeffient.335 shows fund allocation strategies has a positive relationship with project profitability. The coefficient of determination $.112 \mathrm{R}$ square also shows that fund allocation strategies explain $11.2 \%$ of the variability in improved standards. Hence, this implies that the predictors such as constant, consultative project design, Participatory planning and rate of returns affect the progress of improved standards by $11.2 \%$ in Vision City Project.

Therefore, to sustain a project funds need to be strategically allocated and the ownership of the project increase to increase. Hence, there is correlation between participatory planning and project profitability $(\mathrm{p}=.450$ and $\mathrm{sig}=.000)$, participatory planning and stakeholder satisfaction $(\mathrm{p}=.578$ and $\mathrm{sig}=.000)$, rate of returns and project ownership $(\mathrm{p}=.508$ and sig=.000), rate of returns and project profitability $(\mathrm{p}=.363$ and sig=.000), and rate of returns and stakeholder 
satisfaction ( $\mathrm{p}=.536$ and $\mathrm{sig}=.000)$. This implies that there is a positive significant relationship between the measures of project sustainability of vision city in Rwanda.

\subsection{Recommendations}

The findings of the study show that fund allocation strategies promote project sustainability. The fund allocation strategies have seen to be the corners stone of a long time project. Hence, the investors are encouraged to invest in affordable house in order to promote the sustainability of their project in Kigali and secondary cities.

The researcher would like to recommend to the government to continue encourage the private sector, investors and big business owners in allocation their fund in promoting project which can be sustainable and benefit the general public. The government should encourage and formulate policies that are favorable to investors and entrepreneurs who normally invest in the project in order to ensure project sustainability.

The researcher would like to recommend seminars, study tours and workshops to private sector federation to enhance their knowledge and skills on the strategies for allocation of funds in order to ensure the sustainability of both government and private sector. To sustain a project, there must be need for fund and those funds should be well allocated in order to sustain it.

\section{References}

[1].Ababa, T. (2013). Assessing and Moving on From the Dominant Project Management Discourse in the Light of Project Overruns, IEEE Transactions of Engineering Management, 52 (4), 11-23.

[2].Brook, J. W. \& Pagnanelli, F. (2014). Integrating sustainability into innovation project portfolio management: A strategic perspective. Journal of Engineering and Technology Management, 34, 46-62. DOI: http://dx.doi.org/10.1016/j.jengtecman.2013.11.004

[3].Daneshpour, H. (2015). Integrating Sustainability into Management of Project. International Journal of Environmental Science and Development, 6(4), 321-325. DOI: http://dx.doi.org/10.7763/IJESD.2015.V6.611

[4].Ebbesen, J \& Hope, A (2013). Re-imagining the Iron Triangle: Embedding Sustainability into Project Constraints.

[5].International Journal of Business Management, 111(2), 14-19.

[6].Eid, M. (2011). Integrating Sustainable Development into Project management Process. International Journal of Business management, 122(11), 34-40.

[7].Gad, S. H. (2020). Environmental Health and Occupational Toxicology. Doctorate of Public Health. Atlantic International University. USA.

[8].Hope, A. J. \& Moehler, R. (2014). Balancing projects with society and environment: A project, programme and portfolio approach. Procedia: Journal of Social and Behavioral Sciences, 119, 358-367. DOI: http://dx.doi.org/10.1016/j.sbspro.2014.03.041

[9].Peter, O. Kisii, G., Towett, M. Mara, C. \& Luvega, M. (2015). The Dilemma in Sustainability of Community- based Projects in Kenya. Global Journal of Advanced Research, 2 (4), 757-768

[10]. Silvius, A. J. G. \& Schipper, R. (2014). Sustainability in Project Management Competencies: Analyzing the Competence Gap of Project Managers. Journal of Human Resources and Sustainability Studies, 2, 40- 58. DOI: http://dx.doi.org/10.4236/jhrss.2014.22005

[11]. Tufinio, T., Rodney J. \& Ralf, M. (2013) The Project Manager's Role as a Success Factor on Projects: A Literature Review, Project Management Journal, 36 (2), 17-22.

[12]. Transparency International Rwanda (2013). Analysis of the Auditor General Report of the Districts for the $\begin{array}{lllllll}\text { Financial } & \text { Year } & \text { Ended } & 30 & \text { June } & 2011 . & \text { Retrieved at }\end{array}$ https://tirwanda.org/IMG/pdf/auditorgeneralreport_2013_final_english.pdf. 